\title{
DOBRZE ROZWINIĘTY SYSTEM MONITORINGU PODSTAWA BEZPIECZNEJ EKSPLOATACJI OBIEKTÓW HYDROTECHNICZNYCH NA PRZYKŁADZIE OUOW ŻELAZNY MOST
}

\begin{abstract}
W pracy omówiono znaczenie rozbudowanego systemu monitoringu dla bezpiecznej eksploatacji obiektów hydrotechnicznych. W oparciu o system monitoringu zainstalowany na OUOW Żelazny Most będącym przykładem olbrzymiej konstrukcji hydrotechnicznej pokazano jak powinien wyglądać nowoczesny i efektywny system monitoringu umożliwiający praktycznie natychmiastową identyfikację niekorzystnych zjawisk mogących zagrażać bezpieczeństwu budowli. Przedstawiono i w skrócie omówiono zasadnicze elementy tego systemu. Zwrócono również uwagę na istotną rolę niezbędnego wsparcia w postaci bazy danych, gromadzącej, weryfikującej oraz przetwarzającej dane pomiarowe $\mathrm{z}$ systemu monitoringu, co stanowi kluczowy czynnik przy ich szybkiej i skutecznej analizie.
\end{abstract}

Słowa kluczowe: konstrukcje hydrotechniczne, monitoring, aparatura kontrolnopomiarowa, bazy danych

\section{Wprowadzenie}

Bezpieczna eksploatacja każdego obiektu hydrotechnicznego jest nierozerwalnie związana $\mathrm{z}$ obserwowaniem jego bieżącego zachowania oraz detekcją zjawisk, które mogą wskazywać na nieprawidłowe zachowanie zagrażające bezpieczeństwu obiektu. Obiekty hydrotechniczne stanowią skomplikowany system, w którym zachodzą złożone procesy fizyczne związane $\mathrm{z}$ współoddziaływaniem wody i konstrukcji ją utrzymującej, ziemnej lub betonowej. Stąd prawidłowa praca takiego obiektu wymaga bieżącego, szczegółowego monitorowania szeregu parametrów odpowiedzialnych za różne procesy fizyczne zachodzące w trakcie eksploatacji. Sytuacja komplikuje się jeszcze bardziej, gdy mamy do czynienia z bardzo dużym obiektem, który dodatkowo, z racji pełnionej funkcji, jest w ciągłej rozbudowie.

\footnotetext{
${ }^{1}$ Autor do korespondencji/corresponding author: Waldemar Świdziński, IBW PAN, 80-299 Gdańsk, Kościerska 7, waldek@ibwpan.gda.pl

${ }^{2}$ Krzysztof Janicki, KGHM Polska Miedź S.A. Oddział Zakład Hydrotechniczny 59-305 Rudna, ul. Polkowicka 52, Krzysztof.Janicki@kghm.com
} 
Znaczne rozmiary takiego obiektu powodują, że procesy fizyczne, które należy monitorować charakteryzują się dużą zmiennością zarówno ze względu na istotne zróżnicowanie warunków geologicznych i hydrogeologicznych w miejscu lokalizacji, jak też zmienność tych procesów w funkcji czasu z uwagi chociażby na zmieniający się układ naprężeń wywołany przyrostem masy składowanych odpadów czy zmieniające się warunki filtracyjne [3].

Do oceny aktualnego stanu technicznego takiego obiektu hydrotechnicznego oraz prawidłowego jego funkcjonowania, niezbędny jest dobrze rozwinięty system monitoringu. System ten musi obejmować wszystkie te elementy, które mają jakikolwiek wpływ na bezpieczną eksploatację obiektu, a których nieprawidłowe działanie lub niekorzystne zjawiska i procesy fizyczne w nich zachodzące mogą stanowić realne zagrożenie. Dodatkowo, system ten musi być wysoce efektywny w działaniu zapewniając stały dopływ wiarygodnych informacji o stanie obiektu, w dużej mierze zależnych od stanu i jakości funkcjonowania urządzeń monitorujących [2].

Te ogólne założenia są w znacznej mierze spełnione w przypadku systemu monitoringu zainstalowanego na Obiekcie Unieszkodliwiania Odpadów Wydobywczych (OUOW) Żelazny Most KGHM POLSKA MIEDŹ S.A. będącego największym obiektem hydrotechnicznym nie tylko w kraju, ale jednym z największych tego typu obiektów na świecie. W pracy omówiono wszystkie podstawowe elementy systemu monitoringu zainstalowanego na tym obiekcie, zwracając uwagę na te, które są unikatowe z punktu widzenia częstości ich występowania oraz na kompleksowość monitorowanych parametrów i zjawisk mających bezpośredni wpływ na bezpieczeństwo obiektu. Zwrócono również uwagę na niezwykle istotną rolę profesjonalnej bazy danych dedykowanej danemu systemowi w efektywnym gromadzeniu i wiarygodnym analizowaniu dużych ilości danych, pozwalającym na szybką ocenę i identyfikację stopnia zagrożenia bezpieczeństwa obiektu.

\section{OUOW Żelazny Most - podstawowe informacje}

Obiekt Unieszkodliwiania Odpadów Wydobywczych Żelazny Most rozpoczął prace w roku 1977 i od ponad 30 lat stanowi jedyne miejsce deponowania odpadów powstałych $\mathrm{w}$ czasie produkcji rudy miedzi z wszystkich kopalń wchodzących w skład KGHM POLSKA MIEDŹ S.A. Jest więc kluczowym ogniwem, bez którego produkcja miedzi, której sprzedaż przynosi wymierny wkład do krajowego PKB, byłaby niemożliwa. Rocznie deponowanych jest w obiekcie około $28 \mathrm{mln}$ ton odpadów powstających w czasie procesu flotacji, co wymaga przygotowania olbrzymiej przestrzeni do zagospodarowania takiej masy odpadów. Stąd, z racji jedynego miejsca deponowania, obiekt ten musi być bez przerwy rozbudowywany. Rozbudowa obiektu odbywa się tzw. metodą upstream tj. do środka i ku górze, co powoduje, że wysokość zapór ziemnych utrzymujących odpady w jego wnętrzu, ciągle rośnie. W chwili obecnej maksy- 
malna wysokość zapór zbliża się do 70 m, a w długofalowych planach przewiduje się ich podwyższenie o kolejne $15 \mathrm{~m}$. Całkowita powierzchnia obiektu wynosi $14.3 \mathrm{~km}^{2}$ a obwód około $14 \mathrm{~km}$, natomiast objętość zdeponowanych w obiekcie opadów wynosi obecnie około $580 \mathrm{mln} \mathrm{m}^{3}$.

Półpłynne odpady są transportowane do obiektu za pomocą hydrotransportu i zrzucane do jego wnętrza $\mathrm{z}$ korony zapór w postaci mieszaniny wodnogruntowej, wskutek czego odpady podlegają segregacji, co powoduje, że frakcje piaszczyste odkładają się blisko zapór natomiast drobniejsze, wraz z wodą, są transportowane do środka obiektu, gdzie znajduje się staw nadosadowy o pojemności zmieniającej się w przedziale od 5 do $10 \mathrm{mln}^{3}$. Naturalna, grawitacyjna segregacja cząstek stałych odpadów sprawia, że ich masyw charakteryzuje się dużą zmiennością właściwości geotechnicznych zarówno w kierunku poziomym jak i pionowym. Najgrubsze frakcje, zdeponowane blisko korony, są wykorzystywane jako materiał do budowy kolejnych wyższych obwałowań.

Zapory ziemne utrzymujące masyw odpadów są zaporami typu filtracyjnego. Aby kontrolować przepływ wód nadosadowych poza rejon obiekt oraz utrzymywać krzywe filtracji na określonym poziomie obiekt posiada bardzo rozbudowany system drenażu składający się z drenażu zapory podstawowej wraz z drenażami wspomagającymi, rowów opaskowych, drenażu pierścieniowego oraz systemu drenażu pionowego w postaci tzw. studni odciążających oraz studni drenażowych. Więcej informacji można znaleźć w [1] i [4].

\section{System monitoringu OUOW Żelazny Most}

$\mathrm{Z}$ uwagi na rodzaj parametrów rejestrowanych przez urządzenia pomiarowe oraz związane z nimi zjawiska fizyczne, system monitoringu OUOW Żelazny Most można podzielić na następujące elementy:

- monitoring geodezyjny,

- monitoring geotechniczny,

- monitoring hydrogeologiczny,

- monitoring sejsmiczny,

- monitoring hydrologiczny,

- monitoring chemiczny.

Pierwsze cztery elementy monitoringu są bezpośrednio związane $\mathrm{z}$ aktualnym zachowaniem się konstrukcji i jej bezpieczeństwem, natomiast ostatnie dwa z szeroko pojętym oddziaływaniem obiektu na otaczające go środowisko naturalne, który to problem w ostatnim czasie staje się nie mniej ważny. $Z$ uwagi na szczupłość miejsca poniżej zostaną omówione tylko niektóre z nich podkreślając te elementu monitoringu, które oparte są o najbardziej nowoczesne i zaawansowane technologicznie urządzenia i metody pomiarowe. 


\subsection{Monitoring geodezyjny}

Pomiar deformacji konstrukcji jest jednym z dwóch kluczowych elementów w ocenie aktualnego stanu pracy obiektu hydrotechnicznego. Nabiera on jeszcze większego znaczenia w sytuacji, gdy obiekt ten jest w ciągłej rozbudowie, a projektowanie oparte jest o tzw. metodę obserwacyjną. W metodzie tej zakłada się ciągłą weryfikację projektu podczas wznoszenia obiektu w ramach przyjętych dopuszczalnych granic zachowania konstrukcji wyrażonych wartościami dopuszczalnych deformacji i sił wewnętrznych, ustalenie programu monitorowania i planu działań naprawczych wdrażanych w przypadku, gdy obserwacje wykażą zachowania wykraczające poza akceptowane granice [3]. Taka sytuacja ma właśnie miejsce w przypadku Żelaznego Mostu.

Pomiary deformacji (przemieszczeń poziomych i pionowych) OUOW Żelazny Most są przede wszystkim realizowane w ramach okresowych pomiarów geodezyjnych (2-4 razy do roku) prowadzonych na sieci reperów powierzchniowych (około 480) zainstalowanych na zaporach i przedpolu obiektu oraz na reperach wgłębnych posadowionych w podłożu rodzimym do monitorowania osiadań wywołanych rosnącym nadkładem osadów. Pomiary te wykonywane są standardowymi metodami geodezyjnymi za pomocą niwelacji precyzyjnej oraz z wykorzystaniem najnowszych technik GPS. W rejonach, gdzie stwierdzono permanentne występowanie przemieszczeń poziomych, przekraczających błąd ich wyznaczania, zainstalowano stację totalną do ciągłego pomiaru deformacji 23 punktów rozmieszczonych na zaporze oraz indywidualne stacje GPS (4 stacje) do ciągłego pomiaru przemieszczeń w miejscu ich lokalizacji, Rys. 1.

Istotnym elementem monitoringu geodezyjnego, pozwalającym na identyfikację źródła obserwowanych przemieszczeń powierzchniowych, jest pomiar deformacji rur inklinometrycznych. W chwili obecnej na obiekcie zainstalowanych jest łącznie 89 inklinometrów, których maksymalna głębokość dochodzi do $165 \mathrm{~m}$, co jest swoistym rekordem świata! Pomiar deformacji rur inklinome-
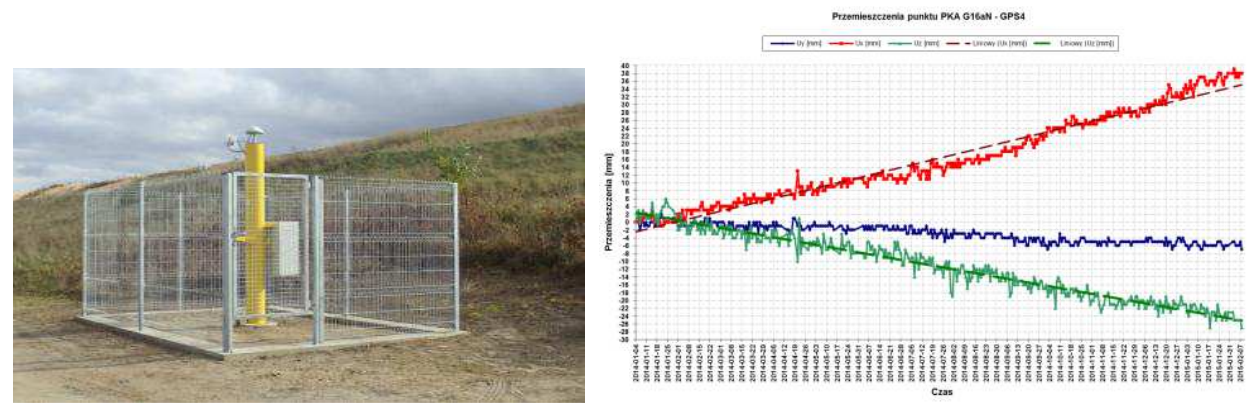

Rys. 1. Stacja GPS do ciągłego, lokalnego pomiaru deformacji zainstalowana na zaporze północnej. Przykładowe wyniki ciągłych pomiarów przemieszczeń poziomych i pionowych

Fig. 1. GPS station for continuous measurement of deformations - North Dam. Vertical and horizontal displacements monitored by the station 
trycznych potwierdził istnienie $\mathrm{w}$ głębokim podłożu rodzimym pod obiektem szeregu powierzchni nieciągłości decydujących o ogólnej stateczności zapór OUOW Żelazny Most. Inklinometry instalowane są zazwyczaj w miejscu stwierdzonych znacznych przemieszczeń powierzchniowych, wzdłuż przekrojów poprzecznych biegnących przez zapory obiektu, co pozwala na identyfikację rozciągłości powierzchni osłabień w głębokim podłożu. Pomiary prowadzone są ręcznie w okresach kwartalnych. W chwili obecnej trwają prace nad wdrożeniem systemu automatycznego pomiaru deformacji inklinometrycznych w wybranych inklinometrach. W ostatnich latach monitoring geodezyjny uzupełniany jest dodatkowo o lotniczy skaning laserowy rejonu obiektu.

\subsection{Monitoring geotechniczny}

Podłoże rodzime pod obiektem charakteryzuje się skomplikowaną budową geologiczną będącą wynikiem szeregu następujących po sobie złożonych procesów geologicznych w dalekiej przeszłości oraz towarzyszących im zjawisk glacitektonicznych i peryglacjalnych. Spowodowały one niekorzystne przekształcenia podłoża rodzimego pod obiektem skutkujące powstaniem szeregu, wspomnianych wcześniej, stref osłabień [1]. Te stosunkowo głęboko leżące strefy uaktywniły się w trakcie rozbudowy obiektu w wyniku rosnącego nacisku wywołanego rosnącym masywem odpadów. Dodatkowo, masyw odpadów utrzymywany przez zapory ziemne charakteryzuje się dużą zmiennością przestrzenną parametrów geotechnicznych i w znacznej części jest nawodniony, co stwarza ryzyko wystąpienia zjawiska upłynnienia.

Bardzo skomplikowana budowa geologiczna podłoża jak też skomplikowane warunki geotechniczne panujące w masywie osadów oraz wspomniany wcześniej fakt ciągłej rozbudowy obiektu i przyjętej do projektowania kolejnych wyższych odcinków zapór, metody obserwacyjnej wymuszają ciągłą aktualizację i weryfikację warunków geotechnicznych. Jest to podstawowy element wiarygodnej oceny aktualnej stateczności zapór obiektu będącej głównym kryterium bezpieczeństwa obiektu.

Stateczność zapór jest oceniana w około 100 płaskich przekrojach biegnących prostopadle przez zapory ziemne okalające składowisko w ramach projektów wykonawczych dla kolejnych wyższych obwałowań w module co $5 \mathrm{~m}$, a dla najbardziej krytycznych 25 przekrojów w module co $2.5 \mathrm{~m}$. Re-interpretacja warunków geotechnicznych w poszczególnych przekrojach jest dokonywana na podstawie wyników rozpoznania geologicznego, hydrogeologicznego oraz geotechnicznego. Rozpoznanie podłoża prowadzi się poprzez wykonywanie głębokich wierceń oraz różnego typu statycznych badań penetracyjnych sondą wciskaną (CPTU/CPTUU i SCPTU) uzupełnionych o badania dylatometryczne (DMT i SDMT) oraz badania geofizyczne typu cross-hole i down-hole. Głębokim wierceniom towarzyszy każdorazowo pobór prób NNS do badań laboratoryjnych z zastosowaniem najwyższych światowych standardów. To samo doty- 
czy badań właściwości osadów, gdzie do poboru prób o nienaruszonej strukturze stosuje się unikatowy próbnik japoński tzw. Push-gel sampler. Rozpoznanie geotechniczne uzupełniają bardzo specjalistyczne badania laboratoryjne (specjalistyczne badania trójosiowe typu TXCIU, $\mathrm{TXCK}_{0} \mathrm{U}, \mathrm{TXEK}_{0} \mathrm{U}$ z pomiarem prędkości fali sejsmicznej zarówno monotoniczne jak i cykliczne, badania w aparacie pierścieniowym, badania edometryczne i konsolidometryczne przy bardzo dużych obciążeniach) [3].

\subsection{Monitoring hydrogeologiczny}

Monitoring hydrogeologiczny łączy w zasadzie elementy monitoringu geotechnicznego związane bezpośrednio $\mathrm{z}$ bezpieczeństwem obiektu (położenie krzywej depresji w masywie osadowe i w zaporach) jak też monitoringu środowiskowego (pole hydrodynamiczne wód podziemnych na przedpolach obiektu). Jest on prowadzony na podstawie obserwacji ciśnień piezometrycznych w blisko 2000 różnego typu piezometrów zainstalowanych w masywie odpadów, na zaporach oraz bliskim i dalekim przedpolu. W przeważającej mierze są to piezometry otwarte, z których część wyposażona została w czujniki do automatycznego pomiaru poziomu zwierciadła wody z próbkowaniem co godzina. Piezometry otwarte służą również do badań środowiskowych (pobór próbek wody do badań jej chemizmu z uwagi na silne zasolenie wód nadosadowych, z których część migruje do wód podziemnych). Dodatkowo, do monitorowania nadwyżki ciśnień porowych w nieprzepuszczalnych warstwach iłów trzeciorzędowych na znacznych głębokościach oraz do oceny efektywności pracy studni odciążających zainstalowanych w celu obniżenia tego ciśnienia, w rurach inklinometrycznych zainstalowano w pełni zautomatyzowane piezometry strunowe (około 300 sztuk). Uzupełnieniem pomiaru piezometrycznego jest comiesięczny pomiar wydatków filtracyjnych prowadzony we wszystkich elementach całego systemu drenażu pionowego i poziomego w celu oceny efektywności działania systemu drenażu jak również monitorowania negatywnych zjawisk filtracyjnych mających wpływ na bezpieczeństwo konstrukcji.

\subsection{Monitoring sejsmiczny}

Z uwagi na położenie obiektu w pobliżu pól wydobywczych jest on narażony na oddziaływanie obciążeń dynamicznych w wyniku losowego występowania wstrząsów górniczych. Do ich rejestracji służy sieć sejsmometryczna składająca się z 18 stanowisk sejsmometrycznych, po dwa w przekrojach najbardziej narażonych na oddziaływania parasejsmiczne (jedno stanowisko na koronie zapory podstawowej, a drugie u jej podnóża, co pozwala na ocenę stopnia amplifikacji rejestrowanych sygnałów). Czujniki akcelerometryczne są wzbudzane każdorazowo, gdy zidentyfikują drgania o określonym poziomie, a rejestracje są przekazywane automatycznie do centralnej bazy sygnałów. Pomiary przyspieszeń uwzględniane są w ocenie stateczności zapór obiektu. 
Pomiary z systemu monitoringu są uzupełniane o wyniki inspekcji wizualnych wykonywanych okresowo na całym obiekcie lub w sytuacjach wystąpienia silniejszego wstrząsu sejsmicznego, zgodnie z zapisami instrukcji eksploatacji obiektu. Stanowi to bardzo ważny element oceny jego aktualnego stanu technicznego. Oceny wizualne stanu składowiska wykonywane są w formie obchodu zapór oraz ich elementów, które maja istotny wpływ na bezpieczeństwo. Obserwacje prowadzone są w cyklach miesięcznych i według stałego schematu, co umożliwia łatwe porównanie stanu stałych elementów zapór. Wyniki obchodu są dokumentowane $\mathrm{w}$ specjalnych formularzach oraz $\mathrm{w}$ formie dokumentacji fotograficznej [2].

\subsection{Baza danych SyZeM}

Wiarygodna i efektywna analiza oraz interpretacja olbrzymiej ilości danych pomiarowych rejestrowanych przez rozbudowany system monitoringu byłaby niemożliwa bez wsparcia wydajnej bazy danych. W przypadku OUOW Żelazny Most taką funkcję $\mathrm{z}$ dużym powodzeniem spełnia zintegrowany system informatyczny SyZeM (System Żelazny Most) oparty na profesjonalnej, relacyjnoobiektowej bazie danych firmy Oracle, która jest zintegrowana z mapą numeryczną rejonu składowiska, utworzoną w środowisku MicroStation, [3]. Baza ta gromadzi wszystkie dane pomiarowe pozyskiwane przez system monitoringu jak też zawiera wszelkie informacje techniczne dotyczące obiektu. SyZeM został zaprojektowany jako system informacji przestrzennej wykorzystujący atrybuty systemu GIS, pozwalające na łączenie informacji graficznej zawartej w mapie obiektowej z informacją opisową zgromadzoną w bazie danych. Dzięki wbudowanym aplikacjom dedykowanym obiektowi, umożliwia on szybki dostęp do pojedynczej danej, co pozwala na praktycznie natychmiastową ocenę stanu bezpieczeństwa oraz potencjalnego stopnia zagrożenia poszczególnych elementów obiektu.

\section{Podsumowanie}

W pracy przedstawiono i w skrócie omówiono zasadnicze elementy systemu monitoringu zainstalowanego na Obiekcie Unieszkodliwiania Odpadów Wydobywczych Żelazny Most, jedynego miejsca deponowania odpadów dla całego zagłębia miedziowego. System ten wykorzystuje nowoczesne urządzenia oraz metody pomiarowe umożliwiające szybką identyfikację potencjalnych zagrożeń mających wpływ na aktualne bezpieczeństwo obiektu. Niezbędnym wsparciem systemu monitoringu stanowi wydajana, profesjonalna baza danych zintegrowana z systemem informacji przestrzennej GIS.

Z uwagi na ilość i jakość zainstalowanej aparatury kontrolno-pomiarowej, kompleksowość i wielość monitorowanych zjawisk i procesów, jak też sposób akwizycji i przetwarzania danych pomiarowych można z pełną odpowiedzialnością powiedzieć, że system monitoringu OUOW Żelazny Most stanowi rodzaj wzorca dla innych obiektów hydrotechnicznych nie tylko w kraju, ale i na świecie. 


\section{Literatura}

[1] Jamiolkowski M. (2014): „Soil mechanics and the observational method: challenges at the Zelazny Most copper tailings disposal facility", Geotechnique, 64, No. 8, 590-619.

[2] Stefanek P., Romaniuk D.: Zastosowanie monitoringu geotechnicznego i środowiskowego na OUOW Żelazny Most, Inżynieria Morska i Geotechnika, 3/2015, 376-381.

[3] Świdziński W., Janicki, K., Krzysik A.: Profesjonalne bazy danych jako niezbędne narzędzie do bezpiecznego projektowania i eksploatacji dużych obiektów hydrotechnicznych na przykładzie składowiska Żelazny Most”, Zeszyty Naukowe Politechniki Gdańskiej, Budownictwo Lądowe, nr 57, Krynica 2006, 335-343.

[4] Świdziński W., Tschuschke, W., Świerczyński W. i Wolski W.: „Obiekt Unieszkodliwiania Odpadów Wydobywczych „Żelazny Most” - olbrzymie wyzwanie geotechniczne", Inżynieria Morska i Geotechnika, 3/2015, 184-191.

\section{WELL DEVELOPED MONITORING AS A BASIS OF SAFE OPERATION OF HYDAULIC STRUCTURES BASED ON ŻELAZNY MOST TAILINGS POND}

\section{S u m m a r y}

In the paper the significance of well-developed monitoring for safe operation of any hydraulic structure is discussed. Based on the example of monitoring system installed on Żelazny Most tailings facility, one of the largest constructions of this type, it was shown how effective monitoring which allows immediate identification of any negative phenomenon threatening safety of the structure should work. The main elements of monitoring system were presented. Special attention was paid to the essential role of database for controlled acquisition, verification and processing of measuring data as necessary support for quick and effective data analysis and interpretation.

Keywords: hydraulic structures, monitoring, measuring devices, databases

Przestano do redakcji: 07.06.2016 $r$.

Przyjęto do druku: $30.06 .2016 \mathrm{r}$.

DOI: $10.7862 / \mathrm{rb} .2016 .58$ 